\title{
22: $22453764-22501255$
}

National Cancer Institute

\section{Source}

National Cancer Institute. 22:22453764-22501255. NCI Thesaurus. Code C45092.

Physical location of SMARCB1_Gene 